\title{
維持血液透析患者における角層水分量と蛮痒の検討
}

\author{
鈴木 千 鈴 平谷 はつ子 奥本 和子 鈴木 加津子 \\ 加 藤 邦子 \\ 松阪中央総合病院血液浄化センター
}

key words：蛊痒症，角層水分量，透析

〈要旨〉

透析患者の皮膚瘙痒症は高頻度で QOL を下げる重要な合併症である. 今回, 透析患者の瘙痒と皮膚乾燥の関連に ついて肌水分計とかゆみスケールを用いて検討した。対象は維持血液透析患者 124 名（男性 72 名·女性 52 名, 平 均年齢 63 歳, 平均透析歴 102 力月, 慢性系球体腎炎 72 名·糖尿病 28 名) と, 健常者 28 名(男性 16 名, 女性 12 名, 平均年齢 61.5 歳) で，肌水分計 (ナショナル DM-RI) を用いて角層水分量を，かゆみスケールを用いて瘋痒度を測 定し検討した. 透析患者の角層水分量は健常者より少なく, 非シャント肢にくらべてシャント肢の方で少なかった. 皮膚㾷㾕症は $37.5 \%$ に認められ, 角層水分量と瘙痒度は負の相関を示した. 角層水分量の多い群と少ない群の比較 では, 多い群で年齢が高く, 少ない群で瘙痒度とリンが高かった，皮膚瘙痒の原因はさまざまな因子の関与が考え られるが, 今回の検討では皮膚乾燥との関連が認められた，今後，皮膚保湿などのスキンケアを実施し，皮膚乾燥 の変化と瘙痒に対する効果について検討する予定である。

\section{Correlation between hydration of stratum corneum and pruritus in maintenance hemodialysis patients}

Chisuzu Suzuki, Hatsuko Hiratani, Kazuko Okumoto, Kazuko Suzuki, Kuniko Kato

Hemodialysis Center, Matsusaka Chuo Hospital

Pruritus is an important complication in hemodialysis (HD) patients, interfering quality of life. In this study, we examined the correlation between xerosis and pruritus in HD patients using a moisture-meter and pruritus scale. The subjects were 124 HD patients ( 72 male, 52 female, mean age 63 years old, mean HD duration 102 months, 72 chronic glomerulonephritis, 52 diabetes mellitus) and 28 healthy controls ( 16 males, 12 female, mean age 61.5 years old). The hydration of the stratum corneum (SC) was assessed by using a moisture-meter (National DM-RI) and pruritus was graded by using a visual analogue scale. Hydration of the SC was lower in the HD patients than in the control group, and was also lower in the arm on AV shunt side than in the arm on the AV shunt-free side. Pruritus was recognized in $37.5 \%$ of HD patients, and a negative correlation was found between the pruritus scale score and hydration of the SC. The patients with a higher degree of hydration of the SC were older, while the patients with a lower degree showed a higher level of phosphorus, and higher pruritus scaling scores. Pruritus in HD patients is known to be due to various factors. However, a significant correlation between pruritus and corneal xerosis was found in this study. Therefore, we will evaluate the effectiveness of skin care, including moisturizing treatment, to manage xerosis and thereby mitigate pruritus.

緒言

皮膚顄痒は透析患者に高頻度に見受けられ, quality of life の低下につながる重要な合併症であるが，確立 した治療法はないのが現状である。透析患者の瘦痒の 原因はさまざまな要因があげられるが，その中でも皮 膚乾燥の関与は大きいと考光られている1,2).今回われ

米田 龍生 奈良県立医科大学泌尿器科 † $634-8522$ 奈良県橿原市四条町 840

Tatsuo Yoneda Tel:0744-22-3051 Fax:0744-22-9282 E-mail : uro-yone@nmu-gw.naramed-u.ac.jp

〔受付：平成 17 年 2 月 23 日, 受理: 平成 17 年 8 月 8 日〕 
われは，透析患者の瘙痒と皮膚乾燥の関連について， 肌水分計とかゆみスケールを用いて調査，検討した。

\section{I . 対象と方法}

\section{1. 対 象}

対象は，平成 15 年 9 月より平成 16 年 4 月までに当 院で維持血液透析療法を施行された患者 124 名で, 性 別は男性 72 名, 女性 52 名, 平均年齡は $63.0 \pm$ 12.1 (19～90) 歳, 平均透析期間は $102 \pm 76.4(4 \sim 326)$ か月, 原疾患は, 糖尿病性腎症 28 名, 慢性糸球体腎炎 72 名, 腎硬化症 11 名, 多発性囊胞腎 6 名であった。ま た, 健常者 28 名 (男性 16 名, 女性 12 名, 平均年齢 $61.5 \pm 6.4$ 歳）をコントロール群とした。

\section{2. 方 法}

\section{1）角層水分量の測定}

角層水分量の測定は肌水分計 (ナショナル, DM-RI) を用いた(図 1).角層は約 20 層の上皮細胞からなる 20 $\mu \mathrm{m}$ 程度の薄い膜で, 水浸透に対する皮膚防御のバリ アを形成しており，その柔軟性は水分に依存してい る3). 角層の水分量が多い場合, 誘電率が高くなり, こ れに比例する静電容量も高くなる. 肌水分計は, 2 つ 電極から構成される小型静電容量センサで電極間の静 電容量を測定し，これに比例する肌水分量を求めるも のであり，角質層の総重量に対する肌水分量の\%で算 出される。一般にヒトの肌水分量の範囲は 15 60\% で，37\%以上で良好な状態とされる。今回，対象の肌 水分量は前腕内側で測定した。透析患者は 1 日空きの 透析前に, シャント肢・非シャント肢別に, 健常者は 左右別に角層水分量測定し，比較検討した。

2 ) 瘙痒度の判定

透析患者で，かゆみスケールを用いて瘙痒度を判定 した（図 2)。スケールは，痒みなしの白色から夜葠ら
れないぐらい痒い耐えられない痒みの赤色までの 2 色 の gradation となっており，患者に痒みの程度を赤色 の濃淡で示してもらい，乙れに対応した裏側に示され ている Visual Analogue' Scale の数值をかゆみスケー ルとした.かゆみスケール 80 以上を高度, 30 以下を軽 度，間を中程度として疰痒の程度を検討した。また， 透析患者に打けるかゆみスケールと角層水分量との相 関について検討した。

3 ）角層水分量と各パラメーターとの相関の検討

透析患者に抢いて角層水分量と各パラメーター [年 齢, 透析歴, 除水量, かゆみスケール，血液検査デー タの, カルシウム $(\mathrm{Ca}) \cdot リ ン ~(\mathrm{P})$ ・インタクト $\mathrm{PTH}$

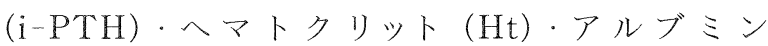
(Alb) · 総蛋白 $(\mathrm{TP})$ ·好酸球]との相関を検討した。

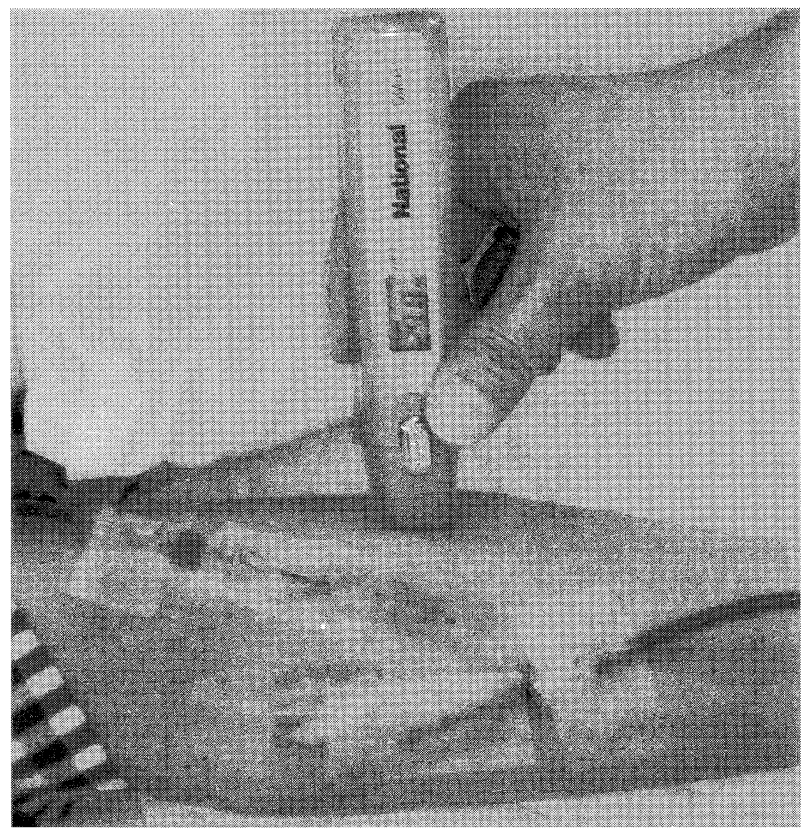

図 1 Measurement for hydration of the stratum corneum with the moisture-meter (National DM-RI).

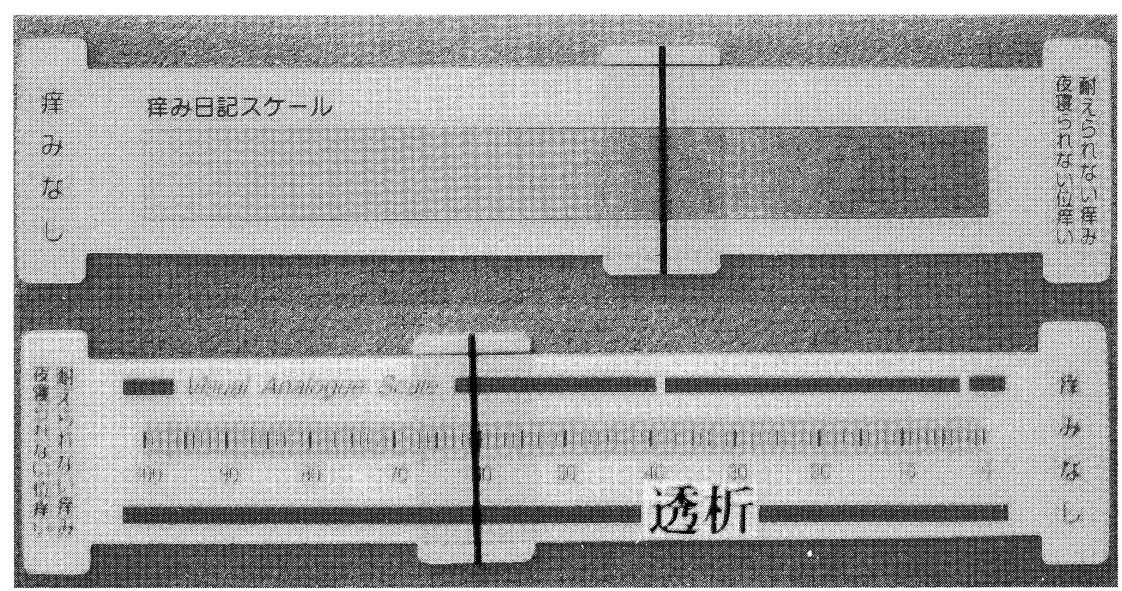

図 2 Pruritus scaling 


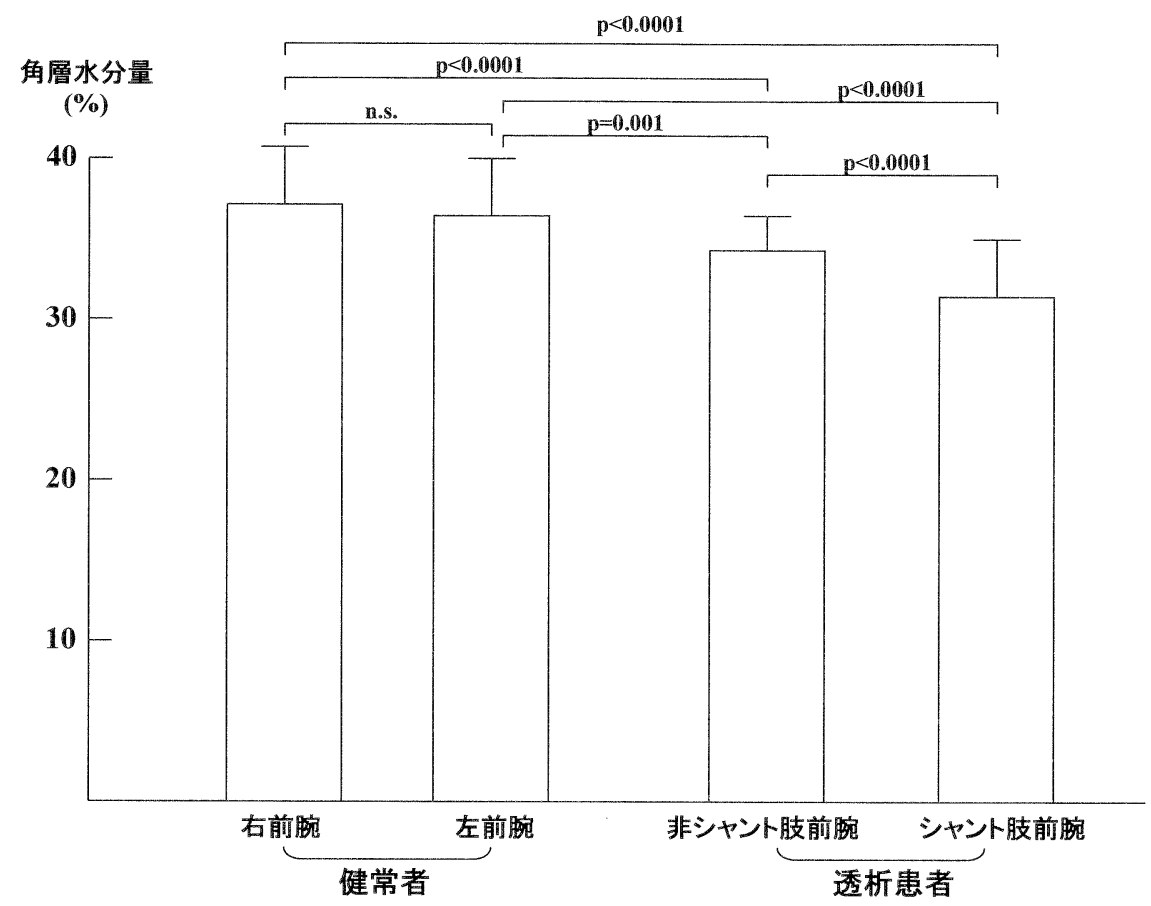

図 3 Comparison of the hydration of the stratum corneum on bilateral arm of hemodialysis patients and controls.

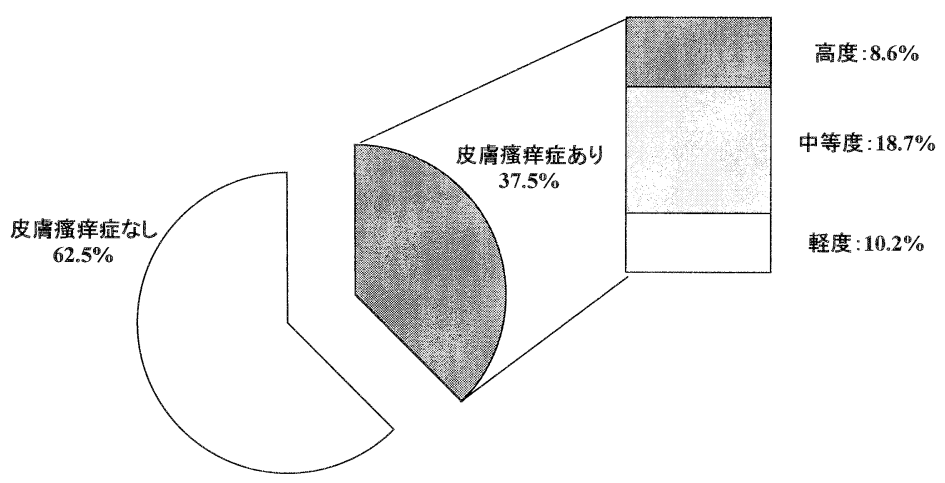

図 4 The degree of pruritus by pruritus scaling.

4）角層水分量の多い群と少ない群の比較 透析患者全員の角層水分量の平均と標準偏差 $(\mathrm{SD})$ から，多い群(角層水分量 $>$ 平均 $+\mathrm{SD}, \mathrm{n}=18$ ) と少な い群 (角層水分量 $<$ 平均 $-\mathrm{SD}, \mathrm{n}=18$ ) に分け，2 群間 で，年歯，透析歴，除水量，かゆみスケール，血液検 查デー夕 $(\mathrm{Ca} \cdot \mathrm{P} \cdot \mathrm{i}-\mathrm{PTH} \cdot \mathrm{Ht} \cdot \mathrm{Alb} \cdot \mathrm{TP} \cdot$ 好酸球 $)$ を比較検討した。

\section{5 ) 統計処理}

2 群間の比較は健常者の左右肢, 透析患者のシャン ト肢・非シャント肢の比較は paired $\mathrm{t}$ 検定で，角層水 分量の多い群と少ない群の比較はStudent $\mathrm{t}$ 検定で, 健常者と透析患者の比較はWelchの $\mathrm{t}$ 検定で施行し た. 2 群間の相関は Pearsonの相関係数を計算した。 いずれも $\mathrm{p}<0.05$ を有意とした。統計処理は統計ソフ ト Dr. SPSS II for Windows（SPSS Inc.）を用いた。

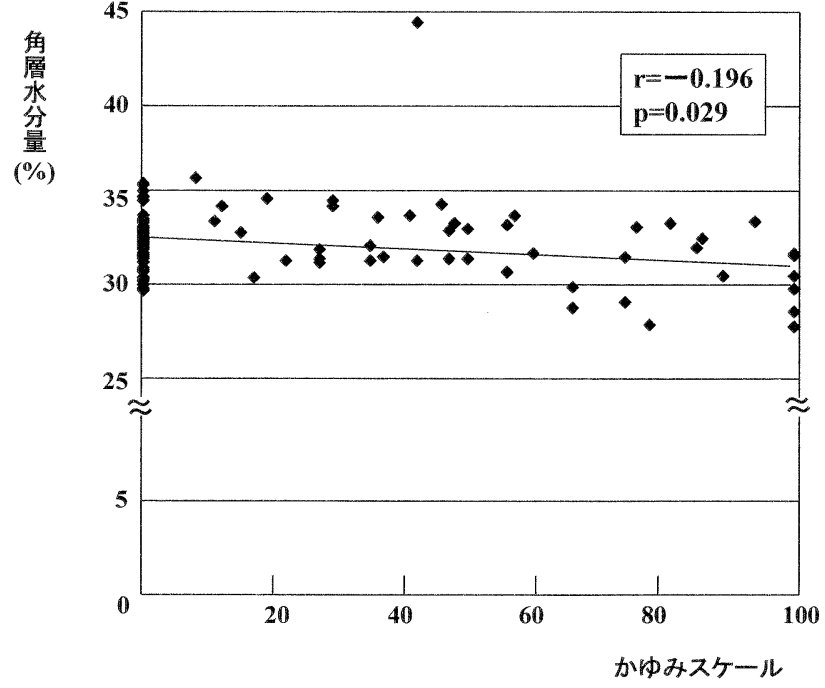

図 5 Corelation between the pruritus scale score and hydration of the stratum corneum. 


\section{II. 結 果}

1. 透析患者に扔ける角層水分量は, シャント肢で $32.3 \pm 1.9$ で, 非シャント肢の $34.0 \pm 2.2$ にくらべて 少なかった $(\mathrm{p}<0.0001)$ 。また, 健常者では左 $36.6 \pm$ 3.6, 右 $37.1 \pm 4.2$ で, 差を認めなかった。透析患者で はシャント肢, 非シャント肢ともに健常者よりも角層 水分量は少なかった（図 3 )。

2。皮膚痖痒症は，全体の $37.5 \%$ に認められ，その 程度は, 高度 $8.6 \%$, 中等度 $18.7 \%$, 軽度 $10.2 \%$ であっ た(図 4).

3. 角層水分量とパラメーターの相関の検討では, 年齢が正の相関を $(\mathrm{r}=0.333, \mathrm{p}<0.0001)$, 除水量 $(\mathrm{r}=-0.206, \mathrm{p}=0.02)$, かゆみスケール $(\mathrm{r}=-0.196$, $\mathrm{p}=0.029)$, リン值 $(\mathrm{r}=-0.314, \mathrm{p}<0.0001)$ が負の 相関を示した（図 5).

4.角層水分量の多い群と少ない群の比較では, 年 歯愉多い群で高く（ $\mathrm{p}=0.0054 ）$ かゆみスケールとリ ンは少ない群で高かった $(p=0.0316, p=0.0472)$ 。透 析歴, 除水量, Ca，i-PTH， Ht， Alb，TP，好酸球は 両群で差を認めなかった（表）。

\section{III. 考 察}

透析患者にみられる皮膚疽痒症は頻度が高く, 65〜84\%に合併するとされていたが ${ }^{4}$ 6), 近年, 透析療 法における技術の進歩により2000年の日本透析医学 会統計調査委員会の報告によると，加みの合併は $40 \%$ と減少してきている7)。われわれの検討では $37.5 \%$ で，皮膚壆痒症の合併はさらに改善傾向である ことが示唆される。

蛮痒の程度と角層水分量は負の相関を示し（図 5), 角層水分量の少ない群でかゆみスケールは高值を示し (表)，皮膚乾燥と瘙痒との関連が示された。維持血液 透析患者の角層水分量は健常者にくらべて低く ${ }^{8 \sim 10)}$, 透析患者では皮脂分泌腺 ${ }^{11)} や$ 汗腺の萎縮 ${ }^{12)}$ ，角層内の 保湿因子の減少9)などの皮膚機能異常に加え，日常生 活でも水分制限が必要となり皮膚乾燥になりやすいと されている。今回のわれわれの検討では，シャント肢 で角層水分量が少なかった。シャント肢は毛細血管の 血流や皮静脈の血流が良好なため皮膚温度が非シャン 卜肢よりも約 $0.3^{\circ} \mathrm{C}$ 高く, 不感蒸泄が多くなり, 皮膚乾 燥が生じることが考えられる。また，シャント肢は穿 刺に際して消毒薬や固定用テープを用いるため, これ らによる皮膚の乾燥も一因であることが推察され
表 Comparison of parameters between higher degree of hydration group and lower degree of hydration group.

\begin{tabular}{lccc}
\hline & 多い群 & 少ない群 & $\mathrm{p}$ \\
\hline 年齢 & $69.1 \pm 10.1$ & $55.3 \pm 15.9$ & 0.0054 \\
透析歴 & $64.6 \pm 80.0$ & $102 \pm 75.6$ & 0.1836 \\
除水量 & $1,365 \pm 621$ & $1,706 \pm 635$ & 0.1286 \\
かゆみスケール & $10.9 \pm 16.0$ & $36.5 \pm 43.9$ & 0.0316 \\
$\mathrm{Ca}$ & $8.99 \pm 1.0$ & $9.12 \pm 1.1$ & 0.5978 \\
$\mathrm{P}$ & $5.29 \pm 0.9$ & $6.28 \pm 1.7$ & 0.0472 \\
$\mathrm{i}-\mathrm{PTH}$ & $218 \pm 124$ & $215 \pm 193$ & 0.9552 \\
$\mathrm{Ht}$ & $31.2 \pm 4.2$ & $32.3 \pm 4.7$ & 0.4544 \\
$\mathrm{Alb}$ & $3.82 \pm 0.38$ & $3.73 \pm 0.50$ & 0.5775 \\
$\mathrm{TP}$ & $6.92 \pm 0.54$ & $6.69 \pm 0.66$ & 0.2960 \\
好酸球 & $4.5 \pm 6.6$ & $3.4 \pm 2.3$ & 0.5304 \\
\hline
\end{tabular}

る ${ }^{13)}$.

今回の検討では，角層水分量の少ない群ではリンが 高値であった。一般に慢性腎不全では排泄障害による 高リン血症が存在し，長期の透析により二次性副甲状 腺機能え進症を惹き起こし，瘙㾕につながると考えら れており，副甲状腺摘除術後に瘙棒の改善が認められ る ${ }^{14)}$ 。今回の検討では PTH と瘙痒の間に関連を認め なかったが，原発性副甲状腺九進症では瘙痒を認めな いことや PTH 皮下注射でも瘙痒の増強を認めないこ となど PTH と瘙痒との関連に関しては否定的な報告 もある ${ }^{15)}$. 瘙痒症例では皮下組織のリンの含有量が多 く, 紫外線照射での瘙痒改善症例では皮下組織のリン 含有量が減少したことから，リン自体の塆痒との関連 性が考えられている ${ }^{16)}$. したがって, 今回の検討におけ る角層水分量と瘙痒との負の相関の背景には高リン血 症の症例が多かったという影響が加味されている可能 性がある。

透析患者の皮膚瘙痒症は上述の乾燥皮膚や高りン血 症, 副甲状腺機能元進症以外にも, ヒスタミン ${ }^{17) や サ フ ゙ ~}$ スタンス $\mathrm{P}^{18)}$, サイトカイン ${ }^{19)}$ サいった瘙痒の mediator の過剰産生や血液透析では除去されない中分子量 物質の影響 ${ }^{20)}$ ， あるいは透析膜や回路の生体不適合性 による反応や透析に関連したへパリンなどの薬剤によ るアレルギー反応など種々の因子の影響が考えられて いる。

一般に角層水分量は加齢によって低下するとされる が，今回の検討では，角層水分量と年齢は正の相関を 示し, 逆の結果となった. 今回の対象のコントロール 群内では年齢と角層水分量の間には関連は認められな かった。また，年齢よりもスキンケアの影響の方が大 きいという意見もあり，必ずしも加齡によって角層水 分量が低下するとは一概にはいえない可能性がある。 さらに，透析患者に扔いては皮膚の汗腺数の減少や機 
能低下により発汗量が低下することにより皮膚乾燥を 生じる。こういった透析特有の角層水分量への影響が 加齢による変化よりも大きいことが示唆される ${ }^{20)}$.

透析患者の瘙痒に関しては多くの因子が関わりその 治療は困難であるが, 今回の検討で当施設での瘙痒に ついて角層水分量との相関を認めたので，今後，皮膚 保湿などのスキンケアを実施していき, 皮膚乾燥の変 化と瘙痒に対する効果について検討する予定である。

\section{結 語}

角層水分量測定により, 皮膚乾燥と痹痒に関連が認 められ, 日常生活指導と食事指導, 保湿剤によるスキ ンケアが重要と考えられた。

なお，本論文の要旨は，第 49 回日本透析医学会総会 (2004 年 6 月, 神戸) で発表した。

\section{文献}

1）柴垣有吾, 内田俊也：未解決の透析合併症, 皮膚搔痒 症の治療は可能か. 臨牀透析 12：95-102，1996

2）奥野仙二：痒みのマネジメント。腎透析と痒み。医薬 ジャーナル 38:3245-3249, 2001

3) Tagami $H$ : Quantitative measurements of water concentration of the stratum corneum in vivo by high-frequency current. Acta Derm Venereol (Stockh) 185(Suppl) : 29-33, 1994

4）荻原洋子：透析患者の皮膚病学一臨床統計を中心に。 東女医大誌 $50 ： 237-251 ， 1980$

5）木嶋祥麿, 前田益孝, 中西太一, 小沢 潔, 仲山 勲, 東海林隆男, 笹岡拓雄, 丸山茂樹, 武本宣教, 毛利郁 二：慢性腎不全の皮膚搔痒症について(第 1 報)。基礎 と臨床 $22: 499-511,1988$

6）段野貴一郎：腎透析患者の痒み。アレルギーの臨床 $18: 436-439,1998$

7）日本透析医学会統計調査委員会：わが国の慢性透析療 法の現況 (2000年 12 月 31 日現在). 日本透析医学会, 2001

8）服部 瑛：腎不全・透析患者のデルマドローム。
Monthly Book デルマ 18：41-48, 1998

9）松村宣子, 田熊淑男, 齀 雅賾, 田上八朗, 小山純一, 伝田光洋，野村淳子：腎透析患者にみられる皮膚の乾 燥性の変化について. 社会保険医学雑誌 $37: 51-55$, 1998

10）大和田滋，外山勝英，前波輝彦，石田尚志：皮膚搔痒 症。日本臨牀 50 (増刊号)：867-872, 1992

11) Rosenthal SR : Uremic dermatitis. Arch Derm Syph $23: 934-936,1931$

12) Landing BH, Wells TR, Williamson ML : Anatomy of eccrine sweat glands in children with chronic renal insufficiency and other fatal chronic diseases. Am J Clin Pathol 54:15-21, 1970

13）太田和夫, 川島 眞, 柴田道子：わが施設のかゆみ対 策. 透析ケア $3: 14-26,1997$

14) Massry SG, Popovtzer MM, Coburn JW, Makoff DL, Maxwell MH, Kleeman CR : Intractable pruritus as a manifestation of secondary hyperparathyroidism in uremia. Disappearance of itching after subtotal parathyroidectomy. N Eng1 J Med 26 : 697700, 1968

15) Stahle-Backdahl $M$ : Uremic pruritus. Clinical and experimental studies. Acta Derm Venereol (Stockh) 145(Supp1) : 1-38, 1989

16) Blachley JD, Blankenship DM, Menter A, Parker TF $3 \mathrm{rd}$, Knochel JP : Uremic pruritus: skin divalent ion content and response to ultraviolet phototherapy. Am J Kidney Dis 5 : 237-241, 1985

17) Cavaillon JM, Poignet JL, Fitting C, Delons S, Pusineri C, Collier C, David B : High in vitro spontaneous histamine release in long-term hemodialyzed patients. J Allergy Clin Immunol 85：859-864, 1990

18) Cho YL, Liu HN, Huang TP, Tarng DC : Uremic pruritus: roles of parathyroid hormone and substance P. J Am Acad Dermatol 36:538-543, 1997

19）段野貴一郎：痒みのメカニズム：よくわかる透析患者 のかゆみケア，p 22-33，金芳堂，京都，2001

20) Dimkovic N, Djukanovic L, Radmilovic A, Bojic P, Juloski $T$ : Uremic pruritus and skin mast cells. Nephron 61:5-9, 1992 